\title{
The Economic, Social and Administrative Pharmacy (ESAP) Discipline in US Schools and Colleges of Pharmacy
}

\author{
Fadi M. Alkhateeb*

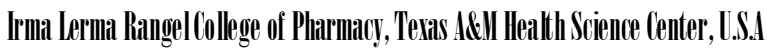 \\ David A. Latif \\ Rachel Adkins \\ School of Phirl'mitcy, Iniversity of Chirleston, L.S.I
}

\begin{abstract}
Schools and colleges of pharmacy in the United States have struggled over the past several decades with identifying a consistent title for the broad body of knowledge related to the social, economic, behavioral, and administrative aspects of pharmacy. This paper examines the educational background and professional experience of those teaching Economic, Social, Administrative Pharmacy (ESAP) content in the United States, to identify the type, frequency, and extent to which ESAP courses are taught in United State's schools and colleges of pharmacy curricula, and to investigate the perceived importance of ESAP content among ESAP faculty. The data was collected by using a 23-item questionnaire was sent via email to 225 ESAP pharmacy faculties in the United States. 96 were returned completed for a 48 percent response rate. Most respondents are not housed in a standalone ESAP department, but would like to be. Both the educational backgrounds of ESAP faculty and the content taught within the discipline vary greatly. This may be because the content within the ESAP discipline is extremely broad. In addition, the diversification in content may be a result of both the diversity of instructor's educational backgrounds and the lack of a generally approved definition for the ESAP field.

Keywords: Economic, Social \& Administrative pharmacy, Pharmacy curriculum, Pharmacy management, Social \& Behavioral pharmacy, Pharmacy Administration

JEL : N32, P36, I25
\end{abstract}

As educational outcomes become more

important in United States curricula, programs of study in different disciplines must analyze their content and reconcile it with optimal learning outcomes needed for future success in these disciplines. One area that should be examined is, " is the discipline' s content so broad given an institution' $s$ resources that it has the potential to dilute optimal learning?" Such is the case with schools and colleges of pharmacy in the United States.

Manuscript received May 5, 2013; revised June 21, 2013; accepted August 15, 2013.

*Corresponding author Email: alkhateeb@pharmacy.tamhsc.edu
Schools and colleges of pharmacy in the United States have struggled over the past several decades with identifying a consistent title for the broad body of knowledge related to the social, economic, behavioral, and administrative aspects of pharmacy. Presently, the discipline is often referred to by several names including Economic, Social, and Administrative Pharmacy (ESAP) (Farley et al., 2010), Economic, Social, and Administrative Sciences (ESAS) (APhA, 2013), pharmacy administration (Leufken et al., 1993; Manasse et al., 1984; Schaefer et al.,1992; Schaefer et al.,1992; Harding et al., 
2006; Harding et al.,1995; Ibrahim et al., 1998; Hassali et al., 2011; Norris 2009; Abrika et al., 2012; Ryan et al., 2007; Anderson, 2008), social and behavioral pharmacy (Wertheimer, 1991; Dolinsky,1990), social and administrative sciences (SAS) (AACP, 2011), and pharmaceutical socioeconomics (University of lowa, 2013). One reason for the confusion is the broadness of the body of knowledge that falls under the general rubric of "ESAP" (Manasse, 1984; AACP, 2011). Different authors refer to the discipline with different names. According to Smith and Knapp, pharmacy administration is referred to as " the socioeconomic determinants of drug use" (Smith et al., 1981). The authors further stated that as pharmacy evolves into a more clinical centered profession, the need for expertise in outcomes related to pharmacy services and drug efficiencies increases (Manasse et al.,1984). Whether the discipline is called ESAP, ESAS, Pharmacy Administration, Social Pharmacy, or another name, it refers to " the endeavor to integrate drugs into a broader perspective and to include legal, ethical, economic, political, social and even communicative as well as psychological aspects into their evaluation in order to contribute to a safe and rational use of drugs" (Schaefer et al., 1992). Since the discipline revolves around economics, social sciences, and administrative sciences as related to the practice of pharmacy, we believe the most appropriate title is Economic, Social, and Administrative Pharmacy. Therefore, for the purposes of this paper, any of the aforementioned variants of ESAP refer to the ESAP discipline. It appears that the discipline includes at least the following: psychology, social science, marketing, management, finance, accounting, public health, and law. Given this breadth it is extremely difficult to accurately coin a term that includes these curricular areas without some confusion. For example the broad field called Business Administration is subdivided into the specific disciplines of Marketing, Management (often subdivided into Organizational Behavior and Management Information Systems), Economics, Accounting, and Finance. These programs seek and hire $\mathrm{Ph}$.D. graduates from these specific disciplines to teach in their areas of specific expertise. In contrast, schools and colleges of pharmacy may hire an ESAP faculty member with a specialty in social science, management, or pharmacoeconomics. Yet, because of the breadth of the discipline, it is unlikely that ESAP faculty members will be comfortable teaching those ESAP content areas in which they have little training and/or interest.

An examination of the educational backgrounds of ESAP faculty in the United States reveals significant variance in ESAP faculty member's Ph.D content areas. For example, Ph.D areas of specialties include communication, public health, history, marketing, management, psychology, geography and economics. Even those faculty members who received their Ph.D degrees from pharmacy schools often have diverse variations in training (Schaefer et al., 1992). Stated differently, it is almost certain that United States pharmacy faculty within the ESAP discipline are not experts in all the different content areas under the ESAP title (Schaefer et 


\section{Alkhateeb et al.}

al., 1992). It is probable that many ESAP faculties know little about some content areas under the ESAP umbrella. For example, are those with expertise in pharmacy law comfortable teaching in accounting? Since many schools and colleges of pharmacy (in particular smaller private schools) have one or two ESAP instructors, the consequence of this is a wide and varied emphasis in the content being delivered.

A germane question one might ask is, "Why is the ESAP discipline content so broad?" The catalyst for this breadth of content can be tied to the American Council of Pharmaceutical Education (ACPE), the accrediting agency for pharmacy programs in the U.S (Ibrahim et al., 1998). In 1975, ACPE included in its standards and guidelines aspects of ESAP content as necessary areas of instruction in pharmacy curricula (Ibrahim et al., 1998). The standards stated that topics such as medical sociology, health care economics, and the management of pharmaceutical services was required. As a result, several United States pharmacy curricula began to add courses and content in administrative, behavioral, and the managerial aspects of pharmacy practice (Ibrahim et al., 1998). In subsequent revisions of the standards, ACPE expanded the required content areas of ESAP to include such areas as communication, law, and ethical principles (Leufkens et al., 1993). The rationale for this expansion has to do with the increased complexity of operating in the health care environment, including drug insurance and cost containment programs (Manasse et al.,1984). According to the 2007 ACPE accreditation standards and guidelines, the
ESAP Sciences include the following topics: Health Care Delivery Systems, Economics/ Pharmacoeconomics, Practice Management, Pharmacoepidemiology, Pharmacy Law and Regulatory Affairs, History of Pharmacy, Ethics, Professional Communication, and Social and Behavioral Aspects of Practice (ACPE, 2007). The breadth of the ACPE standards related to ESAP content is daunting. For example, under "Practice Management" it is expected that schools and colleges of pharmacy train students in accounting, marketing, management, infection control, managed care, and managing and improving the medication-use process, among other guidelines (ACPE, 2007). Institutional response to the ACPE standards has been the increased hiring of ESAP faculty with expertise in various areas such as the health care system, economics, accounting and finance. In addition, according to Manasse and Rucker, ESAP faculty with interest in content areas such as political science, anthropology, communications, spatial geography, computer science, history, architecture and psychology have been hired under the ESAP title at schools and colleges of pharmacy (Manasse et al., 1984).

\section{LITERATURE REVIEW}

\section{ESAP in USA vs. Europe vs. Developing Countries}

Compared to Europe and the developing countries, schools and colleges of pharmacy in the United States have the most developed ESAP program. According to the American Association of Colleges of Pharmacy (AACP) there are 584 full faculty members in Pharmacy Administration at 127 colleges; 40 of them offer graduate 
programs in different areas of ESAP (AACP, 2011). As stated above, ESAP topic requirements are expanding based on the latest ACPE guidelines (ACPE, 2007). Similarly, several European countries incorporated aspects of social pharmacy into their curricula in the mid1970s (Nuffield, 1986). In the United Kingdom (UK) in 1986, the Nuffield Committee advised that behavioral science should be a component of all undergraduate pharmacy curricula (Taylor et al., 2003). Subsequently, the Royal Pharmaceutical Society Working Party on Social and Behavioral Science endorsed this declaration and ESAP content is consistently taught in UK pharmacy curricula. A web-based survey questionnaire pertaining to ESAP content in international schools and colleges of pharmacy was administered in 2007. There were 62 responses received representing 17 countries, including the United States. Results indicated that ESAP content had an international acceptance. However, there was significant variance in what was taught under the ESAP label, ranging from scientific to behavioral science (Ryan et al., 2007; Anderson, 2008)

Pharmacy programs in developing countries such as South Asia and the Middle East place a greater emphasis on basic science fields such as pharmaceutical chemistry and technology, in contrast to clinical and ESAP content (Hassali et al., 2011; Alkhateeb et al., 2010). A reason for the lack of ESAP content may stem from pharmacy educators not understanding the importance and relevance of how ESAP content contributes to educating competent future pharmacists. In addition to a lack of understanding of ESAP relevance, there appears to be a dearth of trained ESAP faculty, and little funding for ESAP research initiatives (Hassali et al., 2011; Alkhateeb et al., 2010)

\section{United States ESAP Courses}

In adherence to ACPE standards, ESAP content is taught to a lesser or greater extent in all accredited schools and colleges of pharmacy in the United States. As previously discussed, because of the significant breadth of ESAP content, and because of the varied backgrounds of faculty who teach ESAP content, there is significant variance in what ESAP content is emphasized in schools and colleges of pharmacy. Course offerings targeting ESAP content may range from introductory content related to the profession of pharmacy and/or the health care system to specialized courses in marketing or pharmacoeconomics. However, there is some consistency across programs. For example, most programs include jurisprudence and varying degrees of health care economics, pharmacy management, financial accounting and planning, and social/behavioral pharmacy (Manasse et al., 1984).

A review of the literature revealed very few studies have investigated the common courses taught in the ESAP field. We could find two studies that have done so, and their scope was global in nature. The first one was done by Leufkens et al. in 1993, to identify the global stance for including ESAP in school curricula (Leufken et al., 1993). Of their responses, 78 percent stated they had a curriculum with courses in ESAP, with 60 percent of those being mandatory and the rest being offered as 


\section{Alkhateeb et al.}

electives. Most of the respondents ranked the most important reason to teach ESAP as being that they felt it better prepared students for " their professional role" (Leufken et al., 1993). The authors reported that the most common ESAP courses that are taught globally include Management (31\%), Legislation and ethics (20\%), Pharmacy practice (17\%), Healthcare system (10\%), Behavioral aspects (10\%) and Epidemiology (3\%) (Leufken et al., 1993)

The second study surveyed 62 respondents representing schools of pharmacy from 17 countries including the US (Ryan et al., 2007). They showed that the main social science disciplines that were being taught around the world under the umbrella of social pharmacy/ESAP, included " communications skills" (60 to 70\%), "law and ethics" (50 to $70 \%)$, " health promotion/education" (40-60\%, and "public health/health policy (40-50\%). Interestingly, the pure social science disciplines, such as sociology (20-30\%), psychology (20\%), anthropology (0-10\%) and geography (0\%) were not taught to a large extent. Other disciplines, such as biostatistics, clinical epidemiology, evidence-based medicine, practicum/externship/ rotation, pharmacoeconomics and healthcare economics, pharmacoepidemiology and pharmacoinformatics, were mentioned by only one respondent each (Ryan et al., 2007).

Student pharmacists with a desire to pursue ESAP content in more detail may be able to take a specialized ESAP related elective while a student pharmacist (Manasse et al.,1984). Alternatively, or in addition to taking a specialized elective, students may enroll in a Masters or Ph.D program upon completion of their PharmD degree (Manasse et al.,1984). According to the AACP website, there are 40 ESAP graduate programs. Eleven of them offer a Masters degree (27.5\%), Eleven offer a Ph.D degree (27.5\%), and eighteen offer both a Masters and a Ph.D degree (45\%) (AACP, 2011). In addition, nearly a third of ESAP graduate programs offer a combined PharmD/Ph.D degree, while approximately onefifth offer a combined PharmD/Masters degree (AACP, 2011).

The overarching goal of ESAP instruction in schools and colleges of pharmacy is to instruct students how to integrate and utilize economic, social and administrative tools to provide quality pharmacy services which will optimize patient outcomes (Hassali et al., 2011). Over the past few decades, the role of the pharmacist has greatly expanded. It is no longer enough to fill the patient' $s$ medication and send them on their way, but now the pharmacist is responsible for counseling to increase patient understanding and also to help manage the patient' $s$ adherence to their medication regimen (Hepler et al., 1990). Much of this has socio-behavioral and economic implications for the health care system. It is vital to understand the patient's socio-behavioral attributes in order to optimize the drug therapy outcomes of the patient. As vitally important, the complexities of the health care system warrant significant training in management, marketing, accounting, and finance.

It seems that schools are starting to view ESAP courses in higher esteem because of ways this type of knowledge can benefit society' $s$ health (Hassali et al., 2011). Those who teach 
International Journal of Management, Economics and Social Sciences

ESAP content face challenges. In addition to the aforementioned challenges that come from varying levels of expertise in the different domains within the ESAP rubric, it may be difficult for many ESAP faculties to establish themselves within the curriculum and the profession (Norris, 2009). For example, one challenge to establish their role in the curriculum is getting other faculty to comprehend the importance of this type of pharmacy teaching. One study by Dolinsky suggests faculty must first educate their colleagues of the benefit of ESAP in pharmaceutical care (Dolinsky, 1990). This article stated that half of the patients taking medications do not take them appropriately as directed by their provider. A pharmacist who is educated in ESAP would be better suited to recognize this type of patient and understand how to communicate with them the importance of medication adherence and understanding (Dolinsky, 1990). Another challenge in establishing their role in the curriculum relates to students. Specifically, many students may not take ESAP content as seriously as they could. In addition, student pharmacists may fail to optimally apply the ESAP content learned from their courses to their future patients. This may contribute to missed opportunities in maximizing the drug-related outcomes of their patients.

The current investigation differs from previous ones in that previous investigations have assessed ESAP course offerings, and faculty perceptions regarding content were global in nature (Leufken et al., 1993; Manasse et al., 1984; Schaefer et al.,1992; Harding et al., 2006; Harding et al.,1995; Ibrahim et al., 1998; Hassali et al., 2011; Norris 2009; Abrika et al., 2012; Ryan et al., 2007; Anderson, 2008). In addition to being global in nature, these investigations are somewhat dated in light of updated ACPE standards and dynamic changes affecting the pharmacy profession. This is the first investigation of solely United States school and colleges of pharmacy ESAP course offerings, and faculty perceptions regarding content.

\section{Objectives}

Because ESAP content is an integral part of United States pharmacy curricula, and because the consistency of ESAP content offerings are so varied, the major goals of this investigation are the following :To identify the educational background and professional experience of those teaching ESAP content in the United States; to identify the type, frequency, and extent to which ESAP courses are taught in United State' s schools and colleges of pharmacy curricula; and to investigate the perceived importance of ESAP content among ESAP faculty.

\section{METHODOLOGY}

\section{Sample}

Population in this research was the pharmacy faculty in the United States that were recognized as members of the social and administrative sciences (SAS) section according to the American Association of Colleges of Pharmacy (AACP) (AACP, 2012). Furthermore, from that population, the research sample measure was 225 names with emails in the SAS list.

\section{Data Collection}

The survey was conducted between July 2010 and of September 2010. The survey was anonymous so that the investigators could not 


\section{Alkhateeb et al.}

identify how respondents responded to the with the current ESAP classes available. In questionnaire items. However, because we addition, respondents were asked to provide offered a financial incentive to complete the information on their perceived positives and survey, we kept track of those who actually negatives regarding ESAP content by using a 5completed the online survey. As a token of appreciation for completing the survey and to increase the response rate, the respondent' $s$ names were entered into a drawing to win one $\$ 100$ gift certificate.

\section{Instruments}

The first email to be sent to ESAP (titled " Social and Administrative Sciences" in the AACP database) faculty contained 23-item questionnaire and an introduction to the purpose of the survey, cover letter, and a link to access the survey. A modified Dillman approach was used to maximize the response rate whereby three reminder emails were sent to the entire sample to help encourage a high response rate (Dillman et al., 2005). The survey was approved by the University Institutional Review Board (IRB). We then used the software SPSS 16 [SPSS Inc. Chicago] to analyze the data we collected.

All the questions that made up the survey were adopted from previous literature that targeted the nature and breadth of ESAP content taught (Schaefer et al.,1992; Anderson, 2008). The survey consisted of three sections and all questions were closed-ended questions. The first section was composed of questions about the faculty' s background and training with questions related to which department they were currently working in and what types of degrees they held. Section two asked demographic questions, and also focused on the ESAP courses available at the respondent' $s$ institution and their satisfaction point Likert-type scale: 1, strongly disagree; 2, disagree; 3, neutral; 4, agree; 5, strongly agree, for each statement. The final section of questions asked institutional demographic information, including location, average class size, number of faculty and whether it was public or private. The pretesting of the survey was conducted by administering the survey to a convenient sample of five ESAP faculties whose names were excluded from the sampling frame for the main study. The faculty' $s$ responses during the pilot study were used to evaluate survey instrument.

\section{RESULTS}

Out of the 225 SAS faculty members who received the survey, 25 were returned as " undeliverable," possibly due to incorrect email addresses or addresses that were no longer in use. So our adjusted sample size for our research was 200. From those who received the survey, 96 were completed with a response rate of 48 percent.

\section{Faculty Background and Training}

The majority of respondents held a degree of Ph.D (90.5\%), with the next highest degrees being BS Pharm (69.4\%) and MS (49.4\%). Only 7.3 percent of respondents held a PharmD degree. When questioned what type of university they attended if they received a Ph.D, 77.1 percent replied a pharmacy school or college, while 8 percent of those earning a Ph.D received it from a school or college of Business. The 
International Journal of Management, Economics and Social Sciences

majority of the respondents were male (62.7\%), were at least 40 years old $(88.3 \%)$, worked at a public institution (60.8\%), and worked at an institution that delivers the Doctor of Pharmacy degree over 4 years $(87.1 \%$ ) (Table 1 - see Appendix-l).

Most faculty answered that they were in the ESAP/pharmacy administration department, 48.4 percent, with 25 percent in the pharmacy practice/clinical pharmacy department while very few in the basic pharmaceutical science department, 9.5 percent. The majority, 71.7 percent, reported they felt being in the ESAP/pharmacy administration department would be the best place to be to optimize their professional growth, while only 13 percent and 5.4 percent, respectively, believed being in the clinical pharmacy/pharmacy practice and basic pharmaceutical science department would achieve this (see Table 2).

\begin{tabular}{|l|l|}
\hline \multicolumn{1}{|c|}{ Academic Department } & \multicolumn{1}{|c|}{$\begin{array}{c}\text { Frequency } \\
\text { (\%) }\end{array}$} \\
\hline \hline Basic pharmaceutical Science & $9(9.5)$ \\
Clinic Pharmacy or practice & $24(25.3)$ \\
ESAP/Pharmacy Administration & $46(48.4)$ \\
Other & $16(16.8)$ \\
\hline \hline Which academic department would & \\
optimize your professional growth? & \\
\hline \hline Basic pharmaceutical Science & $5(5.4)$ \\
Clinic Pharmacy or practice & $12(13.0)$ \\
ESAP/Pharmacy Administration & $66(71.7)$ \\
Other & $9(9.9)$ \\
\hline
\end{tabular}

${ }^{a} \mathrm{~N}$ varies due to item non-response

Table 2: Current and the Preferred Academic Department for ESAP Faculty (n=98)a

ESAP Courses

\section{Position of ESAP in Curriculum}

As far as the ESAP courses available in their pharmacy programs, 65.7 percent reported their curriculum required 3-5 courses per academic year in this area. The most often cited number of electives taught per academic year in ESAP content was one to two courses (44.7\%), with only 17.6 percent of respondents stating that three electives are offered at their institution. Regarding ESAP credit hours taught, the majority of institutions required at least 7-20 credit hours of ESAP courses $(77.7 \%)$ in their curriculum. The majority of respondents stated that they teach 6 credit hours or less per year, The balance of respondents taught 7 to 10 credit hours $(24.7 \%$, and $11-15$ credit hours $(6.4 \%)$. One respondent stated a teaching load of greater than 15 credit hours (Table 3). When asked if they believed their school adequately covered ESAP content, 57.4 percent answered they felt it was sufficient, 42.6 percent answered that it should be more, and 0 percent thought it should be less. (Table 3 - see Appendix-II).

\section{Content of ESAP Courses}

Respondents were asked to discuss the specific content housed in ESAP courses, as measured by contact hours of instruction. The content reported to include 25 or more contact hours were Pharmacy Law and Regulations (50\% of respondents), Clinical Research Methods or Literature Evaluation (40\%), Communications in Health Care (32\%), and Pharmacy Management $(27 \%)$. The contents that included two contact hours or less were Finance (44\%), Organizational 


\section{Alkhateeb et al.}

and/or Consumer Behavior (40\%), and Accounting (34\%) (Table 4 - see Appendix-III).

\section{Challenges for the Teaching of ESAP Courses}

When asked about their feelings about how prepared they felt to teach ESAP courses based on their education, the mean answer was 4.56 (anchored at 1 and 5) which showed that most answered they strongly agreed to feeling prepared. Respondents were asked if they felt more qualified to pursue an administrative position because of their business and management background. The mean response was $3.37 / 5.00$, revealing that most were neutral regarding this. Most respondents believed pharmacy students paid more attention to basic science and pharmacy practice courses than they did to ESAP courses, with a mean answer of 4.16/5.00, meaning they agreed with the statement. Finally, the faculty surveyed felt they taught a wider range of topics in their courses than faculty members of other disciplines with a mean answer of $4.35 / 5.00$, with most agreeing this was true. (Table 4 - see Appendix-IV)

\section{DISCUSSION}

The findings from this study provide valuable information concerning the status of ESAP content in United States pharmacy education curricula. This study reported the perceptions of experts in the field of ESAP regarding ESAP content and its relevance in their institution' $s$ curriculum. We were also able to gain insight into the educational status of ESAP faculty who teach this content, and the differences in courses offered in pharmacy programs throughout the nation.
The first objective of this investigation was to identify the educational background and professional experience of those teaching ESAP content in United States schools and colleges of pharmacy. Our study revealed that those teaching ESAP content have diverse educational backgrounds (Refer to Table 1). Given the enormous breadth of the discipline, it is not surprising that the educational backgrounds are so diverse. The vast majority of respondents obtained a Ph.D (90.5\%), with approximately 77 percent receiving them from schools and colleges of pharmacy. Much like schools of business, ESAP graduate programs of study include diverse training. For example, it is not uncommon for some graduates to be experts in economics, some in marketing and so forth. This may not be an issue in schools and colleges of pharmacy that include four or more ESAP faculty with complementary areas of expertise. It may be a concern in smaller schools and colleges of pharmacy that might employ one or two ESAP faculty. Unless these institutions bridge the expertise gap by asking adjuncts to teach some ESAP content, it might be more challenging to provide student pharmacists with the breadth of content that those institutions with more ESAP faculty provide.

Surprisingly, while approximately 70 percent of ESAP faculty held BS Pharmacy degrees, only 7.3 percent held Doctor of Pharmacy degrees. This shows that most newly graduated pharmacists do not appear to be going into the Social and Administrative fields of academia. This presents some challenges because those ESAP faculty members who are not pharmacists 
International Journal of Management, Economics and Social Sciences

may feel like outsiders in the pharmacy profession (Norris, 2009; Alkhateeb et al., 2010). Similarly, those ESAP faculty members who number two or less (primarily at private institutions with no graduate pharmacy programs) may feel alienated and have difficulty seeking a valid role for ESAP at their institutions. Since most of the respondents were PhDs, it is not surprising that the majority had no type of pharmacy training such as a residency or fellowship. (Refer to Table 1) Of those that did have some type of training, a one year residency was the most popular.

The second investigation objective was to identify the type, frequency, and extent to which ESAP courses are taught in United State' $s$ schools and colleges of pharmacy curricula. As stated previously, the domain of ESAP encompasses many disciplines in business and the social sciences. The majority of respondents stated that their institution required 20 credit hours or less of curricular space devoted to ESAP content. An examination of contact hours devoted to ESAP content shows that the majority of respondent' $s$ stated that less than 9 contact hours is devoted to the topics of accounting, finance, social and behavioral pharmacy, public health, pharmacy marketing, organizational behavior, and epidemiology and pharmacoepidemiology. Given the findings of this study that contact hours for ESAP topics seem low, this may warrant consideration and review by the academy and revision of the requirements for pharmacy school curricular requirements. Given the diverse ESAP content being taught, our results lend support to the 1993 observation by
Schaefer, Leufkens, and Harris that the type, frequency, and extent of ESAP content being taught appears to be highly correlated to the background and expertise of the ESAP faculty member (Ryan et al., 2007).

The third objective was to examine the perceived importance of ESAP content among ESAP faculty. Although the types of courses along with the frequency they are taught appear to vary greatly throughout the nation, each respondent believed that ESAP content is at least sufficient, while 42 percent felt the content should increase. Interestingly, none felt it should be reduced. These results suggest that many ESAP faculty members believe that there exists growth opportunities for the discipline as the profession evolves.

There are several implications of this investigation for schools and colleges of pharmacy in the United States. The ESAP discipline must do a better job of analyzing the tools graduates need to be successful, and make students accountable for mastering these tools. Because of the significant diversity in the backgrounds of those who teach ESAP courses, many may not feel comfortable teaching topics that might be deemed essential to the learning of pharmacy students. Therefore, students may not get this content. For example, if a discipline decides that economic cost benefit analysis is important to graduates of a program, then schools across the United States must include economic cost benefit analysis in their curriculum. Many schools and colleges of pharmacy might have only one faculty member in the ESAP discipline. If a school or college of 


\section{Alkhateeb et al.}

pharmacy hires a faculty member with a degree in history, will students receive the educational outcomes that are deemed important to the pharmacy profession? Therefore, it might be necessary to hire faculty whose expertise is in the major discipline outcomes as opposed to minor discipline outcomes.

Results of this investigation reveal those ESAP faculties face challenges. Despite the fact that they are the minority discipline in schools and colleges of pharmacy, they believe they are asked to teach a broader range of topics than their colleagues in other disciplines. In addition, they believe that student pharmacists hold basic science and pharmacy practice courses in higher regard than they do ESAP courses. It is beyond dispute that ESAP faculty members are asked to teach a very broad range of courses. If students do in fact hold basic science and pharmacy practice courses in higher esteem than they do ESAP courses there are plausible explanations for this. First, ESAP content has very little representation on the North American Pharmacist Licensure Exam (NAPLEX) (NABP, 2010). Therefore, a student pharmacist can become a pharmacist with little knowledge of ESAP content. Second, student pharmacists often pursue the Doctor of Pharmacy degree because of their love for the basic and clinical sciences. Often, those students who are interested in ESAP topics pursue graduate degrees in a business administration or public health discipline.

\section{CONCLUSION}

The growth of ESAP has been steady since it was first introduced in the seventies (Bonnarens,
2011). As the profession transitions to a more patient-centered profession, the importance of ESAP content at schools and colleges of pharmacy in the United States will likely increase (Nwokeji et al., 2005; Nwokeji et al., 2007). Both the educational backgrounds of ESAP faculty and the content taught within the discipline vary greatly. This may be because the content within the ESAP discipline is extremely broad. In addition, the diversification in content may be a result of both the diversity of instructor' $s$ educational background and the lack of a generally approved definition for the ESAP field.

\section{LIMITATIONS AND FUTURE DIRECTIONS}

The results of this study have uncovered several areas where additional research could be valuable. While the scope of this investigation was confined to U.S. schools and colleges of pharmacy, future studies can update previous international studies and extend the present investigation. In addition, an in-depth examination of student pharmacist' $s$ perceptions of the value and benefit of ESAP content may result in educational efforts to provide a greater rationale for ESAP content to student pharmacists.

This study has at least three limitations. First, as it was a self-administered email survey, there is the potential for non-response bias. Financial incentives and repeated contacts were used to try to limit non-response bias. The relatively low response rate of around 48 percent is a limitation of the study in that those who responded may be systematically different than those who did not respond on variables of interest. Moreover, not 
International Journal of Management, Economics and Social Sciences

all ESAP faculties have valid email addresses on the AACP file is a limitation of the study in that those who have valid email addresses may be systematically different than those who have not. Regarding the non-response bias, we did an analysis to make sure that the respondent' $s$ characteristics $(n=96)$ are not different from the sample population $(n=200)$. We made $a$ comparison between respondents and population sample and we found a slight difference between the two groups. For example, the rank of assistant professor, associate professor and professor among responders were 24.2 percent, 32.6 percent, and 41.10 percent, respectively while it was 26.2 percent, 34.2 percent, 39.4 percent, respectively among the sample population. Another example, the male faculties among responders were 62.7 percent while it was 64.8 percent among the sample population (AACP, 2012). Second, the lists of topics and content areas used to evaluate to extent to which ESAP content is being taught at U.S. schools and colleges of pharmacy is not exhaustive. Furthermore, since we did not provide expanded definitions to the list of topics that appear in Table 4, it is possible that some respondents interpreted them differently than others. Finally, an examination of student pharmacist' $s$ perceptions of the value and benefit of ESAP content should have been explored in this study.

\section{REFERENCES}

Abrika, O. S. S., Hassali, M. A. \& Abduelkarem, A. R. (2012). Importance of social pharmacy education in Libyan pharmacy schools: Perspectives from pharmacy practitioners. Journal Of Educational Evaluation For Health Professions, 9(4): 141-148.

Accreditation Council for Pharmacy Education. (2007). 10th edition, Accreditation standards and guidelines for the professional program in pharmacy leading to the doctor of pharmacy degree, Chicago, Illinois. Retrieved May 24, 2012 from https://www.acpeaccredit.org/standards/default. asp

Alkhateeb, F. M., Attarabeen, O. F. \& Latif, D. A. (2010). Pharmacy Administration Education in Colleges of Pharmacy in Jordan. American Journal of Pharmaceutical Education, 74 (5): 117-118.

American Pharmacists Association. (2013). Economic, Social and Administrative Sciences Section (ESAS). Retrieved May 1, 2013 from http://www. pharm acist.com/AM/Template. cfm ?Section=Ec onomic_Social_and_Administrative_Sciences\&Template=/Ta ggedPage/TaggedPageDisplay. $c f m \& T P L I D=87 \&$ Content $\mid D=$ 11102.

American Association of Colleges of Pharmacy. (2012). Social and Administrative Sciences Section. Retrieved May 16, 2013 from http://www. aacp.org/governance/SECTIONS/socialadminsc iences/Pages/default.aspx

Anderson, C. (2008). Social pharmacy: The current scenario. Indian Journal of Pharmacy Practice. 1, 1-5.

Bonnarens, J.K. (2011). What' s Past is Prologue: The history of the discipline of pharmacy administration. Innovations In Pharmacy, 2(2): 1-2.

Dillman, D.A \& Christian, L.M. (2005). Survey mode as a source of instability in responses across surveys. Field Methods, 17(1): 30-52.

Dolinsky, D. (1990). Planning a social/behavioral component of a pharmacy curriculum, American Journal of Pharmaceutical Education, 54 377- 380.

Farley, J. F., Wang, C. C. \& Blalock, S. J. (2010). The status of Ph.D education in economic, social, and administrative sciences between 2005 and 2008. American Journal Of Pharmaceutical Education, 74(7): 126.

Harding, G. \& Taylor, K. (1993). Defining social pharmacy: It needs its own distinct identity. International Journal of Pharmacy Practice, 2(2): 62-63.

Harding, G., \& Taylor, K.M. (2006). Teaching social pharmacy: The UK experience. Pharmacy Education, 6(2): 125-131.

Hassali, M.A., Shafie, A. A., Al-Haddad, M. S. D., Abduelkarem, A. R., Ibrahim, M. I., Palaian, S., \& Abrika, O. S. S. (2011). Social pharmacy as a field of study: The needs and challenges in global pharmacy education. Research in Social and Administrative Pharmac, 7(4): 415420.

Hepler, C.D. \& Strand, L.M. (1990). Opportunities and responsibilities in pharmaceutical care. American Journal of Hospital Pharmacy, 47(3): 533-43.

Ibrahim, M.I.M., Awang, R. \& Razak, A.D. (1998). Introducing social pharmacy courses to pharmacy students in Malaysia. Medical Teacher, 20(2): 122-126.

Leufkens, H.G., Schaefer, M. \& Harris, M.F. (1993). Global survey of teaching of pharmacy administration in colleges of pharmacy. American Journal of Pharmaceutical Education, 57, 74-76.

Manasse, H. R. \& Rucker, T. D. (1984). Pharmacy administration and its relationship to education, research and practice. Journal of Social and Administrative Pharmacy, 2, 127-135.

National Association of Boards of Pharmacy. (2010). Retrieved May 16, 2012 from http://www.nabp.net/programs/examination/naplex/naplexblueprint/

Norris, P.T. (2009). Challenges facing Social Pharmacy. Research in Social and Administrative Pharmacy, 5(3): 195-196. 
Alkhateeb et al.

Nuffield Committee of Inquiry into Pharmacy. (1986). Pharmacy: A report to the Nuffield foundation. London. Retrieved July 19, 2013 from http://hansard. millbanksystems.com/lords/1986/jun/04/ph armacy-nuffield-foundation-report.

Nwokeji, E.D, Rascati, K.L. (2005). Pharmacoeconomic education in colleges of pharmacy outside of the United States. American Journal Of Pharmaceutical Education, 69(3): $1-5$.

Nwokeji, E.D, Rascati, K.L, Moczygemba, L.R. \& Wilson, J.P. (2007). Pharmacoepidemiology Education in US Colleges and Schools of Pharmacy. American Journal Of Pharmaceutical Education, 71(4): 1-5.

Ryan, K., Bissell, P., Anderson, C., Traulsen, J.M. \& Sleath, B. (2007). Teaching social sciences to undergraduate pharmacy students: An international survey. Pharmacy Education, 7, 1-9.

Schaefer, M., Leufkens, H.G. \& Harris, M.F. (1992). The teaching of social pharmacy/pharmacy administration in colleges of pharmacy with special regard to the situation in Germany. Journal Of Social And Administrative Pharmacy, 9(4):141-148.

Smith, M. \& Knapp, D. (1981). Pharmacy, drugs and medical care (3rd ed). Baltimore, MO: The Williams \& Wilkins Co.

Taylor, K., Nettleton, S. \& Harding, G. (2003). Sociology for Pharmacists: An introduction (2nd ed.). New York: Taylor \& Francis.

University of lowa College of Pharmacy. (2012). Graduate program in pharmaceutical socioeconomics. Retrieved May 16, 2012 from http://pharmacy.uiowa.edu/graduateprogram-pharm aceutical-socioeconomics.

Wertheimer, A. (1991). Social/behavioural pharmacy the Minnesota experience. Journal of Clinical Pharmacy and Therapeutics, 16, 381-383.

Westrick, S.C., Kamal, K.M., Moczygemba, L.R., Breland, M.L. \& Heaton, P.C. (2013). Characteristics of Social and Administrative Sciences graduate programs and strategies for student recruitment and future faculty development in the United States. Research in Social \& Administrative Pharmacy, 9(1): 101-107. 
International Journal of Management, Economics and Social Sciences

Appendix-I

\begin{tabular}{|c|c|}
\hline Descriptive Characteristics & Frequency (\%) \\
\hline $\begin{array}{r}\text { Degree } \\
\text { Ph.D }\end{array}$ & $86(90.5)$ \\
\hline Pharm. D & $7(7.3)$ \\
\hline MS & 47 (49.4) \\
\hline MBA & $18(18.9)$ \\
\hline MPH & $3(3.1)$ \\
\hline BS Pharm & $66(69.4)$ \\
\hline J.D & $3(3.1)$ \\
\hline Other & $11(11.5)$ \\
\hline $\begin{array}{l}\text { Pharmacy Training } \\
\text { Residency (one year) }\end{array}$ & $10(10.9)$ \\
\hline Residency (two year) & 0 \\
\hline Fellowship (one year) & $3(3.2)$ \\
\hline Fellowship (two year) & $2(2.1)$ \\
\hline None & $76(83.5)$ \\
\hline $\begin{array}{c}\text { If have Ph. D, what college did you graduate? } \\
\text { Public Health }\end{array}$ & $2(2.3)$ \\
\hline Pharmacy & $67(77.1)$ \\
\hline Medicine & 0 \\
\hline Business & $7(8.1)$ \\
\hline Other & $11(12.5)$ \\
\hline $\begin{array}{l}\text { Administration Duties } \\
\text { Full time }\end{array}$ & $18(18.9)$ \\
\hline Part time (21-35 hrs/wk) & $11(11.6)$ \\
\hline Part time (11-20 hrs/wk) & $8(8.4)$ \\
\hline Part time (10 hours or less) & $14(14.7)$ \\
\hline None & $44(46.4)$ \\
\hline $\begin{array}{c}\text { Academic Rank } \\
\text { Instructor }\end{array}$ & 0 \\
\hline Assistant Professor & $23(24.2)$ \\
\hline Associate Professor & $31(32.6)$ \\
\hline Professor & $39(41.1)$ \\
\hline Other & $2(2.1)$ \\
\hline $\begin{array}{l}\text { Age } \\
\text { Under } 25\end{array}$ & 0 \\
\hline $25-29$ & $3(3.2)$ \\
\hline $30-39$ & $8(8.5)$ \\
\hline $40-49$ & $28(29.8)$ \\
\hline $50-59$ & $30(31.9)$ \\
\hline 60 and above & $25(26.6)$ \\
\hline $\begin{array}{r}\text { Gender } \\
\text { Male }\end{array}$ & $59(62.7)$ \\
\hline Female & $35(37.3)$ \\
\hline
\end{tabular}

Cont... 
Alkhateeb et al.

\begin{tabular}{|c|c|}
\hline Years of full-time work in academia & \\
\hline Less than 3 & $9(9.6)$ \\
\hline $3-7$ & $17(18.1)$ \\
\hline $8-14$ & $24(25.5)$ \\
\hline $15-19$ & $15(15.9)$ \\
\hline $20-29$ & $15(15.9)$ \\
\hline 30 and above & $14(15.0)$ \\
\hline \multicolumn{2}{|l|}{ Pharm D. program at your school } \\
\hline 3-year program & $6(6.5)$ \\
\hline 4-year program & $81(87.1)$ \\
\hline Other & $6(6.4)$ \\
\hline $\begin{array}{l}\text { School or college of pharmacy where you t } \\
\text { Public }\end{array}$ & $56(60.8)$ \\
\hline Private & $36(39.2)$ \\
\hline Number of full-time ESAP faculty & $6(6.5)$ \\
\hline 2 & $15(16.1)$ \\
\hline 3 & $10(10.8)$ \\
\hline 4 & $17(18.3)$ \\
\hline 5 & $14(15.1)$ \\
\hline 6 & $12(12.9)$ \\
\hline More than 6 & $19(20.3)$ \\
\hline $\begin{array}{c}\text { Graduate program in the ESAP } \\
\text { None }\end{array}$ & $40(42.6)$ \\
\hline Master Degree Program Only & $8(8.5)$ \\
\hline Ph. D program & $46(48.9)$ \\
\hline $\begin{array}{c}\text { Class size in School of Pharmacy } \\
\text { Less than } 50\end{array}$ & 0 \\
\hline $50-80$ & $19(20.2)$ \\
\hline $81-100$ & $18(19.1)$ \\
\hline $101-150$ & $30(31.9)$ \\
\hline $151-200$ & $11(11.7)$ \\
\hline More than 200 & $16(17.1)$ \\
\hline
\end{tabular}

Table 1: Descriptive Characteristics of the ESAP Faculty $(n=98)^{a}$

${ }^{\mathrm{a}}: \mathrm{N}$ varies due to item non-response 
International Journal of Management, Economics and Social Sciences

Appendix-II

\begin{tabular}{|c|c|}
\hline & Frequency $(\%)$ \\
\hline $\begin{array}{l}\text { Number of required courses in the curriculum } \\
\text { One course }\end{array}$ & $2(2.2)$ \\
\hline Two courses & $10(10.9)$ \\
\hline Three courses & $17(18.5)$ \\
\hline Four courses & $23(25.3)$ \\
\hline Five courses & $20(21.9)$ \\
\hline Six courses & $9(9.8)$ \\
\hline More than six courses & $10(11.4)$ \\
\hline $\begin{array}{l}\text { Number of elective courses in the curriculum } \\
\text { One course }\end{array}$ & $18(21.2)$ \\
\hline Two courses & $20(23.5)$ \\
\hline Three courses & $15(17.6)$ \\
\hline Four courses & $10(11.8)$ \\
\hline Five courses & $9(10.6)$ \\
\hline Six courses & $2(2.4)$ \\
\hline More than six courses & $11(12.9)$ \\
\hline $\begin{array}{l}\text { Total credit hours required in the curriculum } \\
3 \text { or less }\end{array}$ & $2(2.1)$ \\
\hline $4-6$ & $13(13.8)$ \\
\hline $7-10$ & $20(21.3)$ \\
\hline $11-15$ & $35(37.2)$ \\
\hline $16-20$ & $18(19.2)$ \\
\hline $21-25$ & $3(3.2)$ \\
\hline More than 25 & $3(3.2)$ \\
\hline $\begin{array}{l}\text { Number of required and elective courses credit hours } \\
\text { you teach } \\
3 \text { or less }\end{array}$ & $29(30.1)$ \\
\hline $4-6$ & $35(37.2)$ \\
\hline $7-10$ & $23(24.5)$ \\
\hline $11-15$ & $6(6.4)$ \\
\hline More than 15 & $1(1.8)$ \\
\hline $\begin{array}{c}\text { Is the amount of ESAP courses enough / sufficient at } \\
\text { your pharmacy school? } \\
\text { It is sufficient }\end{array}$ & $54(57.4)$ \\
\hline It should be less & 0 \\
\hline It should be more & $40(42.6)$ \\
\hline
\end{tabular}

Table 3: Required and Elective Courses in the ESAP $(n=98)^{a}$

a: $\mathrm{N}$ varies due to item non-response 
Alkhateeb et al.

\begin{tabular}{|c|c|c|c|c|c|c|}
\hline \multicolumn{7}{|c|}{ Appendix-III } \\
\hline & None & $\begin{array}{l}2 \text { hrs or } \\
\text { less }\end{array}$ & 3-9 hrs & 10-15 hrs & 16-25 hrs & $\begin{array}{l}\text { More than } \\
25 \mathrm{hrs}\end{array}$ \\
\hline Pharmacoeconomics & $\begin{array}{l}0 \\
0 \%\end{array}$ & $\begin{array}{l}13 \\
15 \%\end{array}$ & $\begin{array}{l}33 \\
37 \%\end{array}$ & $\begin{array}{l}12 \\
13 \%\end{array}$ & $\begin{array}{l}14 \\
16 \%\end{array}$ & $\begin{array}{l}17 \\
19 \%\end{array}$ \\
\hline Accounting & $\begin{array}{l}19 \\
22 \%\end{array}$ & $\begin{array}{l}29 \\
34 \%\end{array}$ & $\begin{array}{l}29 \\
34 \%\end{array}$ & $\begin{array}{l}8 \\
9 \%\end{array}$ & $\begin{array}{ll}1 \\
1 \%\end{array}$ & $\begin{array}{ll}0 \\
0 \%\end{array}$ \\
\hline Finance & $\begin{array}{l}15 \\
18 \%\end{array}$ & $\begin{array}{l}37 \\
44 \%\end{array}$ & $\begin{array}{l}24 \\
28 \%\end{array}$ & $\begin{array}{l}9 \\
11 \%\end{array}$ & $\begin{array}{l}0 \\
0 \%\end{array}$ & $\begin{array}{l}0 \\
0 \%\end{array}$ \\
\hline $\begin{array}{l}\text { Social \& Behavioral } \\
\text { Pharmacy }\end{array}$ & $\begin{array}{l}4 \\
5 \%\end{array}$ & $\begin{array}{l}16 \\
18 \%\end{array}$ & $\begin{array}{l}22 \\
25 \%\end{array}$ & $\begin{array}{l}21 \\
24 \%\end{array}$ & $\begin{array}{l}11 \\
13 \%\end{array}$ & $\begin{array}{l}14 \\
16 \%\end{array}$ \\
\hline $\begin{array}{l}\text { US Healthcare System \& } \\
\text { Health Insurance Policy }\end{array}$ & $\begin{array}{l}0 \\
0 \%\end{array}$ & $\begin{array}{l}10 \\
11 \%\end{array}$ & $\begin{array}{l}19 \\
22 \%\end{array}$ & $\begin{array}{l}17 \\
19 \%\end{array}$ & $\begin{array}{l}23 \\
26 \%\end{array}$ & $\begin{array}{l}19 \\
22 \%\end{array}$ \\
\hline $\begin{array}{l}\text { Public Health, Epidemiology } \\
\text { \&Pharmacoepidemology }\end{array}$ & $\begin{array}{l}4 \\
5 \%\end{array}$ & $\begin{array}{l}21 \\
24 \%\end{array}$ & $\begin{array}{l}26 \\
30 \%\end{array}$ & $\begin{array}{l}13 \\
15 \%\end{array}$ & $\begin{array}{l}9 \\
10 \%\end{array}$ & $\begin{array}{l}15 \\
17 \%\end{array}$ \\
\hline Ethics & $\begin{array}{l}0 \\
0 \%\end{array}$ & $\begin{array}{l}25 \\
28 \%\end{array}$ & $\begin{array}{l}27 \\
30 \%\end{array}$ & $\begin{array}{l}13 \\
15 \%\end{array}$ & $\begin{array}{l}8 \\
9 \%\end{array}$ & $\begin{array}{l}16 \\
18 \%\end{array}$ \\
\hline $\begin{array}{l}\text { Communications in Health } \\
\text { Care }\end{array}$ & $\begin{array}{l}2 \\
2 \%\end{array}$ & $\begin{array}{l}12 \\
14 \%\end{array}$ & $\begin{array}{l}17 \\
20 \%\end{array}$ & $\begin{array}{l}15 \\
18 \%\end{array}$ & $\begin{array}{l}11 \\
13 \%\end{array}$ & $\begin{array}{l}27 \\
32 \%\end{array}$ \\
\hline Pharmacy Management & $\begin{array}{l}3 \\
3 \%\end{array}$ & $\begin{array}{l}10 \\
11 \%\end{array}$ & $\begin{array}{l}19 \\
21 \%\end{array}$ & $\begin{array}{l}12 \\
13 \%\end{array}$ & $\begin{array}{l}21 \\
24 \%\end{array}$ & $\begin{array}{l}24 \\
27 \%\end{array}$ \\
\hline Pharmaceutical Marketing & $\begin{array}{l}8 \\
9 \%\end{array}$ & $\begin{array}{l}27 \\
31 \%\end{array}$ & $\begin{array}{l}31 \\
36 \%\end{array}$ & $\begin{array}{l}12 \\
14 \%\end{array}$ & $\begin{array}{l}7 \\
8 \%\end{array}$ & $\begin{array}{l}1 \\
1 \%\end{array}$ \\
\hline $\begin{array}{l}\text { Organizational or Consumer } \\
\text { behavioral }\end{array}$ & $\begin{array}{l}11 \\
13 \%\end{array}$ & $\begin{array}{l}33 \\
40 \%\end{array}$ & $\begin{array}{l}33 \\
40 \%\end{array}$ & $\begin{array}{l}3 \\
4 \%\end{array}$ & $\begin{array}{l}2 \\
2 \%\end{array}$ & $\begin{array}{l}0 \\
0 \%\end{array}$ \\
\hline $\begin{array}{l}\text { Clinic Research Methods or } \\
\text { Literature Evaluation }\end{array}$ & $\begin{array}{l}1 \\
1 \%\end{array}$ & $\begin{array}{l}9 \\
10 \%\end{array}$ & $\begin{array}{l}9 \\
10 \%\end{array}$ & $\begin{array}{l}9 \\
10 \%\end{array}$ & $\begin{array}{l}17 \\
20 \%\end{array}$ & $\begin{array}{l}35 \\
40 \%\end{array}$ \\
\hline $\begin{array}{l}\text { Pharmacy Law \& } \\
\text { Regulations }\end{array}$ & $\begin{array}{l}0 \\
0 \%\end{array}$ & $\begin{array}{l}10 \\
11 \%\end{array}$ & $\begin{array}{l}10 \\
11 \%\end{array}$ & $\begin{array}{l}3 \\
3 \%\end{array}$ & $\begin{array}{l}18 \\
20 \%\end{array}$ & $\begin{array}{l}45 \\
50 \%\end{array}$ \\
\hline
\end{tabular}

Table 4: Contents/Contact Hours of the ESAP Curriculum (n=98) ${ }^{a}$

a: $\mathrm{N}$ varies due to item non-response 
International Journal of Management, Economics and Social Sciences

Appendix-IV

\begin{tabular}{|c|c|c|c|c|c|c|c|}
\hline Statement $^{b}$ & SD & D & $\mathbf{N}$ & $\mathbf{A}$ & SA & Mean & $\begin{array}{c}\text { Medi } \\
\text { an }\end{array}$ \\
\hline $\begin{array}{l}\text { a. I feel that my education } \\
\text { has prepared me well to } \\
\text { teach the ESAP at my } \\
\text { current school }\end{array}$ & $0(0 \%)$ & $1(1 \%)$ & $4(4 \%)$ & $28(30 \%)$ & $61(65 \%)$ & 4.56 & 5 \\
\hline $\begin{array}{l}\text { b. I believe ESAP faculty } \\
\text { members are more } \\
\text { qualified to pursue } \\
\text { administrator position in } \\
\text { the pharmacy school } \\
\text { because of their business } \\
\text { and management } \\
\text { education } \\
\end{array}$ & $5(5 \%)$ & $13(14 \%)$ & $34(36 \%)$ & $26(28 \%)$ & $16(17 \%)$ & 3.37 & 3 \\
\hline $\begin{array}{l}\text { c. Pharmacy students pay } \\
\text { more attention to the } \\
\text { basic science and } \\
\text { pharmacy practice than } \\
\text { for our courses. }\end{array}$ & $0(0 \%)$ & $7(7 \%)$ & $7(7 \%)$ & $44(47 \%)$ & $36(38 \%)$ & 4.16 & 4 \\
\hline $\begin{array}{l}\text { d. ESAP faculty members } \\
\text { teach a wider range of } \\
\text { topics than faculty from } \\
\text { other disciplines } \\
\end{array}$ & $2(2 \%)$ & $3(3 \%)$ & $22(23 \%)$ & $26(28 \%)$ & $41(44 \%)$ & 4.35 & 4 \\
\hline
\end{tabular}

Table 5: Challenges for the ESAP Faculty $(n=98)^{a}$

SD strongly disagree, D disagree, $\mathrm{N}$ neutral, A agree, SA strongly agree

a: $\mathrm{N}$ varies due to item non-response

${ }^{\mathrm{b}}$ All the items were measured by Likert scale $1=$ strongly disagree, $2=$ disagree, $3=$ neutral, $4=$ agree, $5=$ strongly agree 